\title{
Intermédialités
}

Histoire et théorie des arts, des lettres et des techniques

Intermediality

History and Theory of the Arts, Literature and Technologies

\section{Modernity and the Face}

\section{Margaret Werth}

Numéro 8, automne 2006

Envisager

Facing

URI : https://id.erudit.org/iderudit/1005541ar

DOI : https://doi.org/10.7202/1005541ar

Aller au sommaire du numéro

Éditeur(s)

Centre de recherche sur l'intermédialité

ISSN

1705-8546 (imprimé)

1920-3136 (numérique)

Découvrir la revue

Citer cet article

Werth, M. (2006). Modernity and the Face. Intermédialités / Intermediality, (8), 83-102. https://doi.org/10.7202/1005541ar
Résumé de l'article

$\mathrm{Au}$ tournant du $\mathrm{XX}$ e siècle, le visage adopte de nouvelles formes, des nouvelles fonctions et des nouvelles significations. Les représentations de l'identité, les valeurs esthétiques, tout autant que l'expérience sociale et individuelle à travers le visage se trouvent modifiées. Les études que Georg Simmel consacre à la question de la modernité et au statut privilégié du visage sont liées de près a une reconfiguration du visage en littérature (Proust), en art (Redon) et au cinéma (le gros plan), révélant une dislocation des oppositions entre intériorité et extériorité, entre proximité et distance, entre l’humain et la machine. 


\title{
Modernity and the Face
}

\author{
Margaret Werth
}

round 1900, the face took on new forms, functions, and meanings.

Modes of figuring identity and aesthetic value or registering individual and social experience through the face changed. Older ideas of physiognomy or pathognomy intersected with new ideas and practices for recording, viewing, and interpreting faces in daily life and in the arts and sciences. ${ }^{1}$ During this period, questions were being raised about the universality of facial expression, the normative and deviant models of facial morphology, and how the face might be pictured. Within capitalist, metropolitan culture, faces circulated in an accelerating system of exchange and consumption, and the face was a privileged form within the transformations of modernity.

Identity, physiognomy, and expression became increasingly ambiguous or opaque in visual modernism, producing unreadable faces and ambivalent gazes. The human face was pictured in a new relation to space, time, and expression in flash and motion photography and early film. Experts in medicine, psychology, sociology, ethnography, and evolutionary biology documented and debated facial evolution, variation, and expression. Facial expressions and gestures were studied as part of the symptomatology of nervous illness and exploited as part of urban entertainment. In mass culture, faces were invested with affect and communicative functions that would be both heightened and eroded by repetition and commodification. New technologies and media shaped the recording and representation of the face, modifying the codes and modes of "reading" it.

1. See the discussion, for example, of physiognomy and its representation in Tom Gunning, "In Your Face: Physiognomy, Photography, and the Gnostic Mission of Early Film," Modernism/Modernity, Vol. 4, No. 1, 1997, p. 1-29. 
In his studies on the psychology, philosophy, and sociology of modernity, Georg Simmel outlined the dissociation and distanciation characteristic of everyday urban life: mutual reserve and indifference; the blasé attitude; a retreat into inner, psychological life as a response to reified, objective culture and the pressure of the metropolitan crowd. ${ }^{2}$ He proposed that modernity privileged the face because it showed "human beings in the flux of their inner life," and that the conversion of concrete experience into inner experience was a primary tendency of modernity. ${ }^{3}$ In his essay "Sociology of the Senses" of 1908, Simmel maintained that as the first object of interaction between one person and another, the face is "the symbol of everything that an individual has brought with him or her," the face "tells" and is the "essential object of inter-individual seeing." The face, he argued, is important to our knowledge and experience of individuality, and offers the visual form of persisting inwardness as well as of shifting immediacy.5 The face-and particularly the eyes-are potent and active agents of reciprocity: the interaction created through the mutual gaze creates a unity that is suspended in the event of the mutual look ("the eye cannot take without simultaneously giving"). ${ }^{6}$ This reciprocity is vital to human relationships and radically different from acts of seeing such as observation of another person, but it is fragile and subject to the vicissitudes of even subtle deviations from the mutual look and facingness.7 In Simmel's account of modernity, the face is increasingly a focus of visual attention.

Simmel's 1901 essay on the face, "The Aesthetic Significance of the Face," sought to account for the intrinsic aesthetic qualities of the face and its significance in art. Of all the parts of the body, Simmel argued, the face had the highest degree of inner unity, a unity achieved out of variety and diversity-comparable to the ideal of human cooperation-and a unity closest to the inner unity of the mind. The face was the preeminent sign of man's appearance: it revealed the soul "clearly and ultimately;" "the emotions typical of the individual [...]

2. Georg Simmel, "The Metropolis and Mental Life" [1903], trans. Edward A. Shils, in Georg Simmel: On Individuality and Social Forms: Selected Writings, Donald N. Levine (ed.), Chicago, University of Chicago Press, coll. "The Heritage of Sociology," 1971, p. 324-339.

3. Georg Simmel, Michel-Ange et Rodin, trans. Sabine Cornille, Philippe Ivernel, Paris, Éditions Rivages, coll. "Petite bibliothèque," 1989 [1909], p. 103.

4. Georg Simmel, "Sociology of the Senses" [1908], trans. Mark Ritter and David Frisby, in Simmel on Culture: Selected Writings, David Frisby and Mike Featherstone (eds.), London, Sage Publications, coll. “Theory, Culture \& Society," 1997, p. 113.

5. Georg Simmel, "Sociology of the Senses," p. 113.

6. Georg Simmel, "Sociology of the Senses," p. 115.

7. Georg Simmel, "Sociology of the Senses," p. 111-112. 
leave lasting traces"; the face's "singular malleability" made it the "geometric locus $[\ldots]$ of the inner personality." Christianity's tendency to "cover the body and represent man's appearance solely by his face, has been the schoolmaster for those who would seek consciousness of individuality." 8 The face is intrinsically aesthetic because art elucidates the formal elements of things in relation to one another, and the face as a whole responds to the alteration of the smallest element: the face is the aesthetic synthesis of symmetry (de-individualization) and asymmetry (individualization). (ASF, p. 279) The face's mobility is invested in it even when at rest: "as if this state of rest were the non-extended moment toward which innumerable movements have tended, from which innumerable movements will come." (ASF, p. 280)

Simmel's essay on the face argued for its importance within modernity and in relation to art: the face was a means of studying the forms of human social life as they appeared in the "mirror" of the face, reflecting modern "inner life." The face's achieved unity and the mutual determination of its elements were a model for Simmel's theory of modern society and culture. His comments on the face's mobility are linked to his emphasis on modernity's relativity and restless desirousness, its ceaseless flux. However, the face of modern inner experience (increasingly distanced from concrete experience), the face of contingency and mobility, was ultimately aestheticized and idealized in Simmel's account. He ended his essay with a consideration of the heightened "dynamic effect" of the eye as it epitomized "the achievement of the face in mirroring the soul" and served also as the "interpreter of mere appearance, which knows no going back to any pure intellectuality behind the appearance." (ASF, p. 281) His account of the face meshes uncertainly, however, with his account of modernity as a retreat into inner, psychological life in the context of the alienation, objectification, neurasthenia, and fragmentation of metropolitan culture. The contradictions and instabilities of the face might work against convergence and mirroring, and against the possibility of a "solution of those other problems which involve soul and appearance" such that "[a]ppearance would then become the veiling and unveiling of the soul." (ASF, p. 281) If, as Simmel argues, the face is aesthetically significant and an exemplary form of the "subjectivism" of modernity, how was the face figured in the arts around 1900? I will consider three examples from literature, the visual arts, and early film.

8. Georg Simmel, “The Aesthetic Significance of the Face [1901]," trans. Lore Ferguson, in Georg Simmel, Essays on Sociology, Philosophy and Aesthetics, Kurt H. Wolff (ed.), p. 278-279. Henceforth, references to this article will be indicated by the initials "ASF," followed by the page number, and placed between parentheses in the body of the text. 


\section{KISSING ALBERTINE}

In a passage on shifting facial proximity in Marcel Proust's À la recherche du temps perdu, the narrator describes kissing Albertine, the face in whose study he had adopted so many different optical instruments: "ayant fait sortir de son cadre lointain le visage fleuri que j'avais choisi entre tous, je l'aurai amené dans ce plan nouveau." But the kiss,

“[...] en accélérant prodigieusement la rapidité des changements de perspective et des changements de coloration que nous offre une personne dans nos diverses rencontres avec elle [...] c'est dix Albertines que je vis; cette seule jeune fille étant comme une déesse à plusieurs têtes, celle que j'avais vue en dernier, si je tentais de m'approcher d'elle, faisait place à une autre."

Proust describes the disorienting experience of the close-up view of the face-the lack of horizon or center, the collapse of figure/ground distinctions and I/you relations-whose effects of magnification and proximity result in vertigo and inhuman facelessness (a loss of unity or features) or many-headedness. Albertine loses her identity as a singular individual and even as a subject as she is transformed from lover into monstrous goddess. Proust compares the multiplication of aspects of her face to the effects of photographs where near and far are collapsed through angle of view, framing, and reflection. (LCG, p. 660) In Proust's novel, kissing Albertine is like the experience of the cinematic close-up. The familiarity of the face and its strangeness are conjoined in the moment of the kiss when proximity and distance collide and intertwine.

In another passage of Proust's novel, the narrator recounts the eruption of a facial paroxysm on the face of his friend, Robert de Saint-Loup, at the moment he reveals his betrayal of Marcel. The friend presents his vulgar deed with the comment "Voilà comme je suis, j'aime les situations tranchées," his face

[...] stigmatisée pendant qu'il me disait ces paroles vulgaires par une affreuse sinuosité que je ne lui ai vue qu'une fois ou deux dans la vie, et qui, suivant d'abord à peu près le milieu de la figure, une fois arrivée aux lèvres les tordait, leur donnait une expression hideuse de bassesse, presque de bestialité toute passagère et sans doute ancestrale. Il devait y avoir dans ces moments-là [...] éclipse partielle de son propre moi, par le passage sur lui de la personnalité d'un aïeul qui s’y reflétait. (LCG, p. 693)

This face is haunted by its double: marked by an involuntary spasm as it registers two personalities-and two temporalities-paradoxically accompanying

9. Marcel Proust, Le côté de Guermantes [1920], in À la recherche du temps perdu, Vol. 2, Paris, Éditions Gallimard, 1988, Jean-Yves Tadié (ed.), p. 659-66o. Henceforth, references to this text will be indicated by the initial " $\mathrm{LCG}$," followed by the page number, and placed in parentheses in the body of the text. 
Saint-Loup's wish for clear cut situations ("situations tranchées"). Here the face is mobile, its expression an event, its unity and integrity interrupted. In a passage on Marcel watching Albertine sleep, Proust offers a different mode of splitting and doubling, this time in alternating profile and frontal views of the face:

[...] les lettres que vous écrit quelqu'un [sont] à peu près semblables entre elles et dessinent une image assez différente de la personne qu'on connaît pour qu'elles constituent une deuxième personnalité [...] Mais combien il est plus étrange qu'une femme soit accolée [...] à une autre femme dont la beauté différente fait induire un autre caractère, et que pour voir l'une il faille se placer de profil, pour l'autre de face. ${ }^{10}$

Further on in La prisonnière, the narrator listens to the voice of a lover on the telephone and wonders why painters who

[...] cherchent à renouveler les portraits féminins du XVIII siècle où l'ingénieuse mise en scène est un prétexte aux expressions de l'attente, de la bouderie, de l'intérêt, de la rêverie, comment aucun de nos modernes Boucher ou Fragonard, ne peignit, au lieu de "la lettre", ou "du clavecin", etc., cette scène qui pourrait s'appeler: "Devant le téléphone", et où naîtrait spontanément sur les lèvres de l'écouteuse un sourire d'autant plus vrai qu'il sait n'être pas vu. ${ }^{11}$

The telephone produces a new mode of attention-and a new technology of the face and facial expression-one that Marcel thinks is ripe for painting and that will show the expressivity and interiority of the responsive and absorbed face of the "unobserved" listener, comparable to the music listener or letter reader of the 18 th century portrait or genre painting. The telephone overcomes distance and separation, giving access to the lover's psychic states (expectation, sulkiness, interest, reverie), yet the voyeuristic situation Marcel envisions reinstates distance rather than intimacy or reciprocity.

The telephone-face seems to have been far more fertile for early cinema, however, than for painting. Alternating between telephoning victims and rescuers, for example, was an exciting feature of early films-not, however, necessarily signifying absorption or intimate expression or, for that matter, confined to listening, but working as a device for building temporal, spatial, and psychological tensions that would be resolved in the final rescue. An early Pathé film of 1908, for example, tells the story of a doctor's wife left alone at home with her child who is able to signal for help by telephone: the film cuts between medium close-ups of wife and husband, as the wife frantically conveys her plight and her husband assures her of rescue. (Figs. 4-5) Proust's telephone-face is that of an absorbed and silent listener, but it is also the object of voyeurism, crossed by both language

10. Marcel Proust, La prisonnière [1923], in À la recherche du temps perdu, vol. 3, p. $5^{81 .}$

11. Marcel Proust, La prisonnière, p. 607. 
and vision. Following Gilles Deleuze, we might say that Proust's faces of the kiss and the facial paroxysm (and the telephone-faces of Le médecin du château) are intensive faces in which the unity and boundaries of the face are broken-as is individual subjectivity - while Proust's telephone-face is reflective or reflexive, the features "groupés sous la domination d'une pensée" the face fixed and immutable within a "ligne enveloppante" a "plaque réceptive d'inscription."

\section{THE FACE, WHAT A HORROR}

Odilon Redon's noirs (his black and white works) also experiment with the face. In Redon's works of the 188 os and 1890 , the face is put into a new relation to the body, time, and space. It seems to carry what survives of identity, physiognomy, and subjectivity, but is often separated from the body and even the head, which often stands for the body in its absence. Simmel comments on the relationship between body, head, and face: "the unity of the face is accentuated by the head's resting on the neck, which gives the head a sort of peninsular position vis-à-vis the body and makes it seem to depend on itself alone [...]" (ASF, p. 277) Redon's faces attach to or wrap around heads often segmented or separated from the body. They explore a wide range of expressive qualities or states: somnambulistic catatonia, fascination, moronic inertia or infantilism, serene contemplation, childlike wonder, absorption, hopeful striving, glee, surprise, astonishment, cynicism, absurdity, dread, disgust-and suggest to the viewer a complex and often ambivalent range of responses. Redon's noirs launch a process of substitution and layering of expressions and affects, refusing unified subjectivity and engendering facial polymorphism.

Redon experimented with many faces: the petrified face; the face turning in on itself, turning towards, or away, from the viewer; the face dominated by a single eye; the traumatized face, on a severed head; the hybrid or monstrous face (the human face joined to the body of a spider, a flower, a rock); the beatific martyrface; the suffering face of Christ. He explored the dynamics of anthropomorphism, the shock of the non-human becoming human and of the human becoming plant or animal. In Redon's faces the composition of facial traits is often disrupted through exaggeration, displacement, or elision. The eyes often diverge or dissociate. In works like La gloire fausse (circa 1885) or the cyclops from his album Les origines (fig. 1), for example, enlarged eyes turn upwards, gaping, and the face becomes centrifugal, impelled toward otherness. Such faces are "abstruse and aesthetically unbearable" according to Simmel, pointing to "the loss of senses,

12. Gilles Deleuze, Cinéma 1. L'image-mouvement, Paris, Éditions de Minuit, coll. "Critique," 1983 , p. 125-128. 


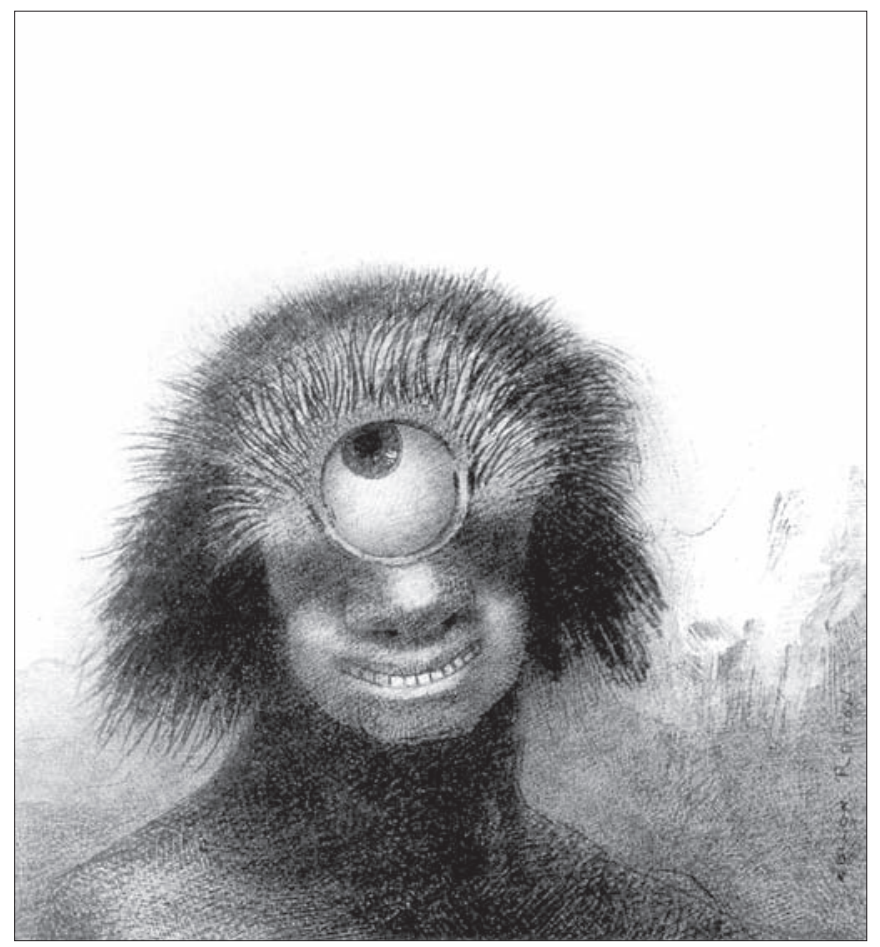

Fig. 1. Odilon Redon, "Le polype difforme flottait sur les rivages, sorte de cyclope souriant et hideux," Plate III from Les origines, 1883 .

spiritual paralysis, momentary absence of spiritual control," in short "despiritualization." (ASF, p. 278) Redon's faces on severed heads figure the trauma of separation and loss; the confusion of life and death, of absorption and vacancy; and the shock of a subject witnessing its own death. They break down the distinction between interiority and exteriority and introduce an impossible temporality.

In his albums, Redon experimented with the arrangement and sequencing of faces and the combinatory potential of text and image. His album Hommage à Goya (1885) begins and ends with close-up faces: "Dans mon rêve, je vis au Ciel un VISAGE DE MYSTÈRE" (fig. 2) is a figure of anticipation, desire, anxiety, and dread that inaugurates the dream; "Au réveil, j'aperçus la DÉESSE de L'INTELLIGIBLE au profil sévère et dur" ends the album with the goddess's face emerging out of the darkness, as if from under a hooded mask. Between these framing faces are those of a marsh flower, a madman, embryonic beings, and a juggler. (Fig. 3) The image series moves through a complex set of variations between the fixed and unfixed, the human and inhuman. The face is successively decomposed and displaced, then recomposed in the last plate as the "profil sévère et dur" of 


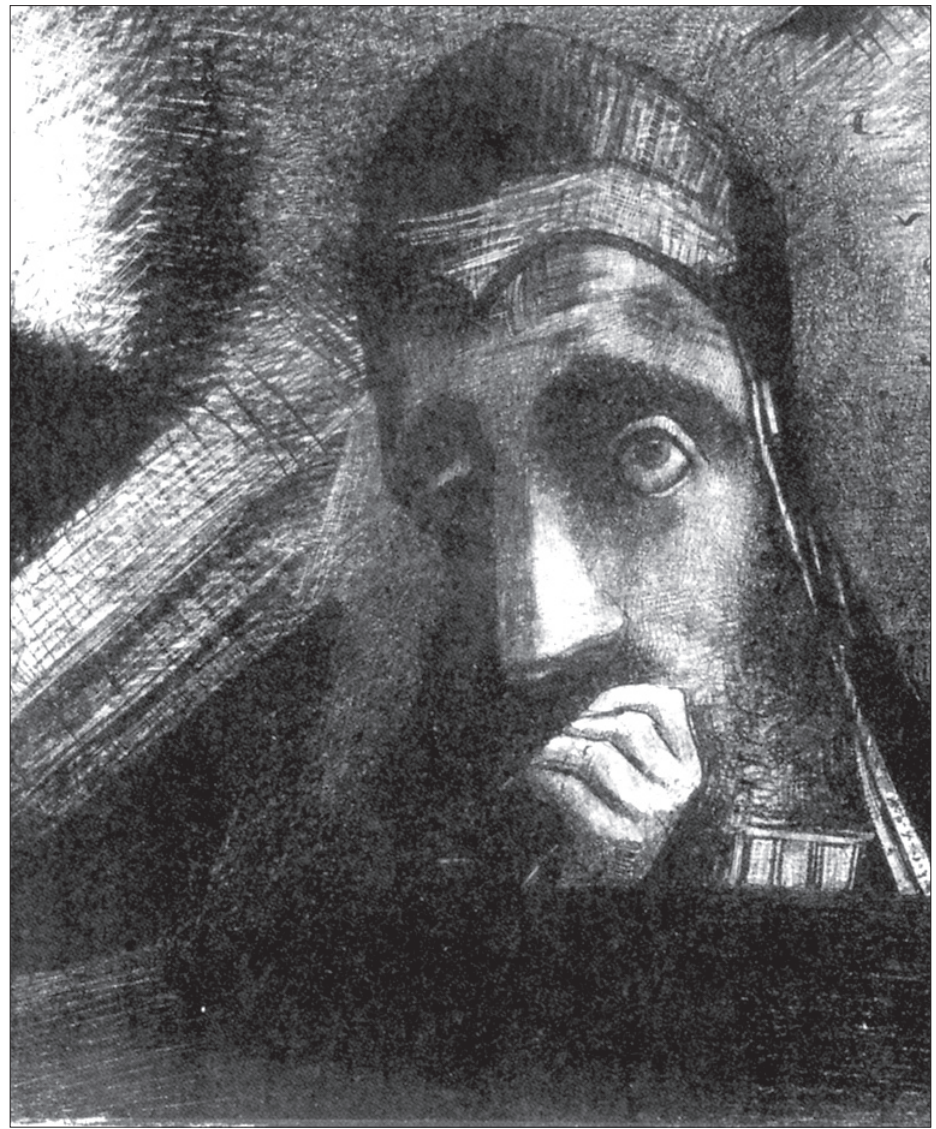

Fig. 2. Odilon Redon, "Dans mon rêve, je vis au Ciel un VISAGE DE MYSTÈRE," Plate 1 from Hommage à Goya, 1885 .

intelligibility. The images are paired with captions that structure the sequence, but the series permits undetermined associations and reversals, allowing a folding of the different faces-the faces of difference-and the affects they provoke.

Medium, form, and their interaction are important to the production of faces in Redon's noirs - whether he works in charcoal or transfer lithography, whether rendering atmospheric light and shade or linear arabesque. As he wrote:

[T] out mon art est limité aux seules ressources du clair-obscur et il doit aussi beaucoup aux effets de la ligne abstraite, cet agent de source profonde agissant directement sur l'esprit $[\ldots]$ 


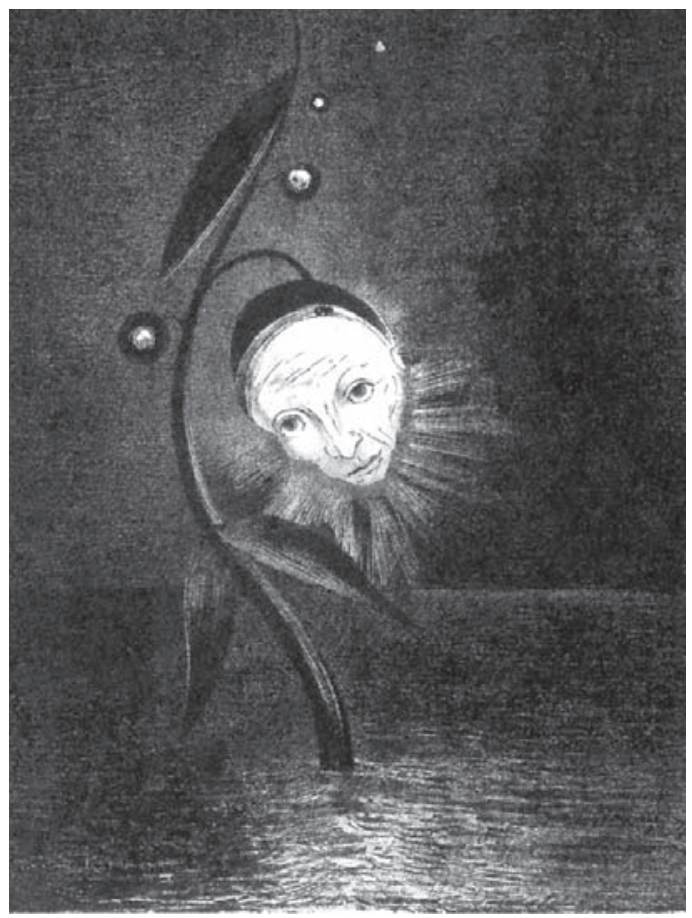

Fig. 3. Odilon Redon, "La FLEUR du MARÉCAGE, une tête humaine et triste,” Plate II from Hommage à Goya, 1885.

Imaginez des arabesques ou méandres variés, se déroulant non sur un plan, mais dans l'espace, avec tout ce que fourniront pour l'esprit les marges profondes et indéterminées du ciel; imaginez le jeu de leurs lignes projetées et combinées avec les éléments les plus divers, y compris celui du visage humain; si ce visage a les particularités de celui que nous apercevons quotidiennement dans la rue, avec sa vérité fortuite immédiate toute réelle, vous aurez, là, la combinaison ordinaire de beaucoup de mes dessins.

Ils sont donc, sans autre explication qui ne se peut guère plus précise, la répercussion d'une expression humaine placée, par fantaisie permise, dans un jeu d'arabesque, où, je crois bien, l'action qui en dérivera dans l'esprit du spectateur l'incitera à des fictions dont les significations seront grandes ou petites, selon sa sensibilité et selon son aptitude imaginative à tout agrandir ou rapetisser. ${ }^{13}$

13. Odilon Redon, À soi-même: journal (1867-1915), Paris, Librairie José Corti, 1979, p. 25 et 27 . 
Chiaroscuro and abstract line establish Redon's figures against their ground, yet also open the image to indeterminacy and disfiguration. The pairing of plates with captions introduces intermedial effects. On the one hand the captions of the album constitute a prose poem:

Dans mon rêve, je vis au Ciel un VISAGE DE MYSTĖRE / La FLEUR du MARÉCAGE, une tête humaine et triste / Un FOU dans un morne paysage / Il y eut aussi des Êtres EMBRYONNAIRES / Un étrange JONGLEUR / Au réveil, j'aperçus la DÉESSE de L'INTELLIGIBLE au profil sévère et dur. ${ }^{14}$

Rather than completing or determining meaning the captions create their own "chiaroscuro" and "ligne abstraite." Captions and images form a complex text, the inaugural "Dans mon rêve, je vis au Ciel" accompanying an image of what is seen in the dream, followed by a series of seers and other things seen, from the marsh flower to the strange juggler, each vertical pairing of image and caption carried through the horizontal axis of the album. As individual units images and captions multiply in a series that accumulates instances of dream vision. The last plate's caption repeats the action of the first ("Ie vis...," "J'aperçus..."), but also announces a different kind of seeing, "au réveil," outside the dream. The I/eye of the captions mirrors the reader/viewer's, constructing a gaze that moves through the serial accumulation and modes of distortion, never meeting an answering gaze in the figures imaged. The text's capitalizations (VISAGE DE MYSTĖRE / FLEUR du MARÉCAGE / Un FOU / Êtres EMBRYONNAIRES / JONGLEUR / DÉESSE de LINTELLIGIBLE) title the images, name the figures, and punctuate the texts within and between the captions: they are typographic figures on the ground of the caption and the page, and inked shadows on the ground of the white paper, participating in the chiaroscuro of the album visually, and in their unfixed play of associations, textually. Threaded through the series the captions are "arabesques" as well, part of the "jeu [...] projeté" and "répercussion d'une expression" Redon speaks of: as dark lines and forms against the white; as narration ("Dans mon rêve, je vis") and, in their openness and indeterminacy "arabesques ou méandres variés, se déroulant non sur un plan, mais dans l'espace." The dreaming, seeing, being, and waking the captions voice speak to the lithographic images and the faces of monstrosity, madness, emergence, obliteration, and fixation. The spacing between text and text, text and image, and image and image creates a differential and temporal tension that accumulates and disseminates in the process of reading/viewing the album.

14. "In my Dream I Saw in the Sky a FACE OF MYSTERY; The MARSH FLOWER, a Sad Human Head; A MADMAN in a Dismal Landscape; There Were also EMBRYONIC BEINGS; A Strange JUGGLER; Upon Waking, I Saw the GODDESS of the INTELLIGIBLE, with her Severe and Hard Profile." 
The faces of Redon's Hommage à Goya are radically unstable signs. Reflective, self-reflexive faces (the face of Mystery, the Marshflower) appear in settings that compromise their inwardness and boundedness (indeterminate sky above, marshwater below), and are nested in successions of faces whose inwardness and boundedness are eroded or even shattered (the Madman, the Juggler). There is an unsettling mixture of intimacy and distance in Redon's work, and a dislocation of oppositions of figure and ground, interiority and exteriority, mobility and fixation. The emphasis on the figures' faces produces a sense of intensified encounter as does the album format and the emphatic address of the text, but ultimately Hommage à Goya works to disarticulate subjectivity: affects (anticipation, surprise, fear) ebb and flow indeterminately, unanchored; and the too close and too far intertwine. ${ }^{15}$

Simmel addresses proximity and distance and the mutual dependency of the internal and external life within modernity in Die Philosophie des Geldes. ${ }^{16}$ There he argues that art brings us close by putting us at a distance through aesthetic organization, and that in modernity there is a tendency toward an increase in the distance produced by transposing objects into art, particularly through

$[\ldots]$ the felt charm of the fragment, the mere allusion, the aphorism, the symbol, the undeveloped artistic style [...]. Here the distance that art already places between ourselves and the objects is extended yet a stage further, in that the notions that form the content of the ultimately stimulating psychic experience no longer have a visible counterpart in the work of art itself, but are only provoked by perceptions of quite a different kind. In all this we discover an emotional trait whose pathological deformation is the so-called "agoraphobia:" the fear of coming into too close a contact with objects, a consequence of hyperaesthesia for which every direct and energetic disturbance causes pain [...]. [T] he subjectivism of modern times has the

15. For a discussion of the close-up face and affect see Gilles Deleuze, "Limageaffection: visage et gros-plan" in L'image-mouvement, p. 125-144. See also his discussion of monsters and Redon in Différence et répétition, where he writes: "Pour produire un monstre, c'est une pauvre recette d'entasser des déterminations hétéroclites ou de surdéterminer l'animal. Il vaut mieux faire monter le fond, et dissoudre la forme. Goya procédait par l'aquatinte et l'eau-forte, la grisaille de l'une et la rigueur de l'autre. Odilon Redon, par le clair-obscur et la ligne abstraite. En renonçant au modelé, c'est-à-dire au symbole plastique de la forme, la ligne abstraite acquiert toute sa force, et participe au fond d'autant plus violemment quielle s'en distingue sans qu'il se distingue d'elle. À quel point les visages se déforment dans un tel miroir." (Gilles Deleuze, Différence et répétition, Paris, Presses universitaires de France, 1972, p. 44)

16. Georg Simmel, The Philosophy of Money, trans. Tom Bottomore and David Frisby from a first draft by Kaethe Mengelberg, David Frisby (ed.), London, Routledge Press, 2nd edition, 1990 [1900]. See, in particular, p. 470-479. 
same basic motive as art: to gain a more intimate and truer relationship to objects by dissociating ourselves from them and retreating into ourselves, or by consciously acknowledging the inevitable distance between ourselves and objects. ${ }^{17}$

Also, "there exists a deep inner connection between too close a captivation with things and too great a distance from them which, with a kind of fear of contact, places us in a vacuum." ${ }^{18}$ Redon's dislocation of subjectivity, I would argue, positions the reader/viewer in this "vacuum."

\section{MOVING FACES}

It took some time for the face to become prominent in moving images. Experiments with recording the moving face photographically-the "living portraits"

94 of the phonoscope or the trick films of Meliès and others, or early "facial expression" films that emphasized the monstrosity, curiosity, and comedy of the face in full-screen enlargement-were soon overtaken by other interests, notably the insertion of facial close-ups in narrative films. Early close-ups were often seen as grotesque, obscene, and in bad taste, breaking the continuity of the film. ${ }^{19}$ Faces were included in medium or long shot, with only the occasional close-up; they were shown (silently) talking and animated by marked facial gestures and expressions. New modes of displaying the face in early film emerged around 1913-1915 as

17. Georg Simmel, The Philosophy of Money, p. 474. Within modernity, money functions to create a culture of mutual distancing: "For the jostling crowdedness and the motley disorder of metropolitan communication would simply be unbearable without such psychological distance. Since contemporary urban culture, with its commercial, professional and social intercourse, forces us to be physically close to an enormous number of people, sensitive and nervous modern people would sink completely into despair if the objectification of social relationships did not bring with it an inner boundary and reserve." (Georg Simmel, The Philosophy of Money, p. 477)

18. Georg Simmel, "Der Krieg und die geistigen Entscheidungen" [1917], quoted in David Frisby, Fragments of Modernity: Theories of Modernity in the Work of Simmel, Kracauer and Benjamin, Cambridge, Massachusetts, MIT Press, 1986 [1985], p. 75. On the importance of Simmel's use of the concept of distance and proximity see also Donald Levine, "The Structure of Simmel's Social Thought," in Georg Simmel: Essays on Sociology, Philosophy and Aesthetics, Kurt Wolff (ed.), Columbus, Ohio State University Press, 1959, p. 9-32.

19. Tom Gunning discusses early examples of facial close-ups in film and cites an announcement of a film of 1902, Comic Grimacer, that advertises the screen-size human face as "always a comic and interesting sight." He emphasizes the encounter between the popular and scientific traditions in the representation of faces. See Tom Gunning, "In Your Face," p. 15-17, p. 21-25. 
natural (less theatrical and exaggerated) expressions became more common and more medium close-ups and full close-ups centered on the face appeared. By the late 1910 s and 1920s, the face was ubiquitous as a focus of interest and close-ups of the face were increasingly common. ${ }^{20}$

In recent years, film historians and theorists have reflected on the close-up, reconsidering earlier theorizations by Jean Epstein and Béla Balázs, in particular. ${ }^{21}$ Tom Gunning has criticized the "overdetermined fascination with the closeup and the human face" and Mary Ann Doane the "excessiveness and exuberance" of the historical discourse on the close-up; and both writers have discussed the two somewhat contradictory aspects of the close-up of the face-proximity or enlargement-although Gunning has been concerned with early "curiosity" or "attraction" films rather than the later narrative films on which Doane concentrates. ${ }^{22}$ The filmic close-up, Doane writes, inhabits "the gigantic, the spectacular, the space of the big screen," and these are allied to consumerism, the commodity, and industrial capitalism. ${ }^{23}$

Simmel's discussion of proximity and distance and the new relations of internal and external life is relevant here. The money economy both conquers distance (it brings things close, sometimes unbearably so, to the point of agoraphobia) and creates distance (objectifies and abstracts, enlarges and spectacularizes).

\section{SUDDENLY A FRIGHTENED FACE}

Close-up views of the face bring things close at the same time that they produce distance and estrangement: faces appear in detail, fragmented from the body, with mobile surfaces, movements, and gazes that point to and construct space both inside and outside the frame. Faces are magnified and enlarged to monstrous scale and situated within a new structuring of space and time; they conjoin the detail and the gigantic, proximity and distance. Two examples suggest

20. Jacques Aumont, Du visage au cinéma, Paris, Éditions de L’Étoile, 1992, p. 68.

21. See Jean Epstein, "Magnification and Other Writings," trans. Stuart Liebman, October, No. 3, 1977, p. 9-25; and Béla Balázs, Theory of the Film: Character and Growth of a New Art, trans. Edith Bone, New York, Dover, 1970.

22. See Tom Gunning, "In Your Face," and Mary Ann Doane, "The Close-Up: Scale and Detail in the Cinema," Differences, Vol. 14, No. 5, 2005, p. 89-111.

23. "As simultaneously microcosm and macrocosm, the miniature and the gigantic, the close-up acts as a nodal point linking the ideologies of intimacy and interiority to public space and the authority of the monumental. In the close-up, the cinema plays simultaneously with the desire for totalization and its impossibility. The cinematic spectator clings to the fragment of a partial reality-a fragment that mimics the effect of a self-sufficient totality." (Mary Ann Doane, “The Close-Up,” p. 109) 

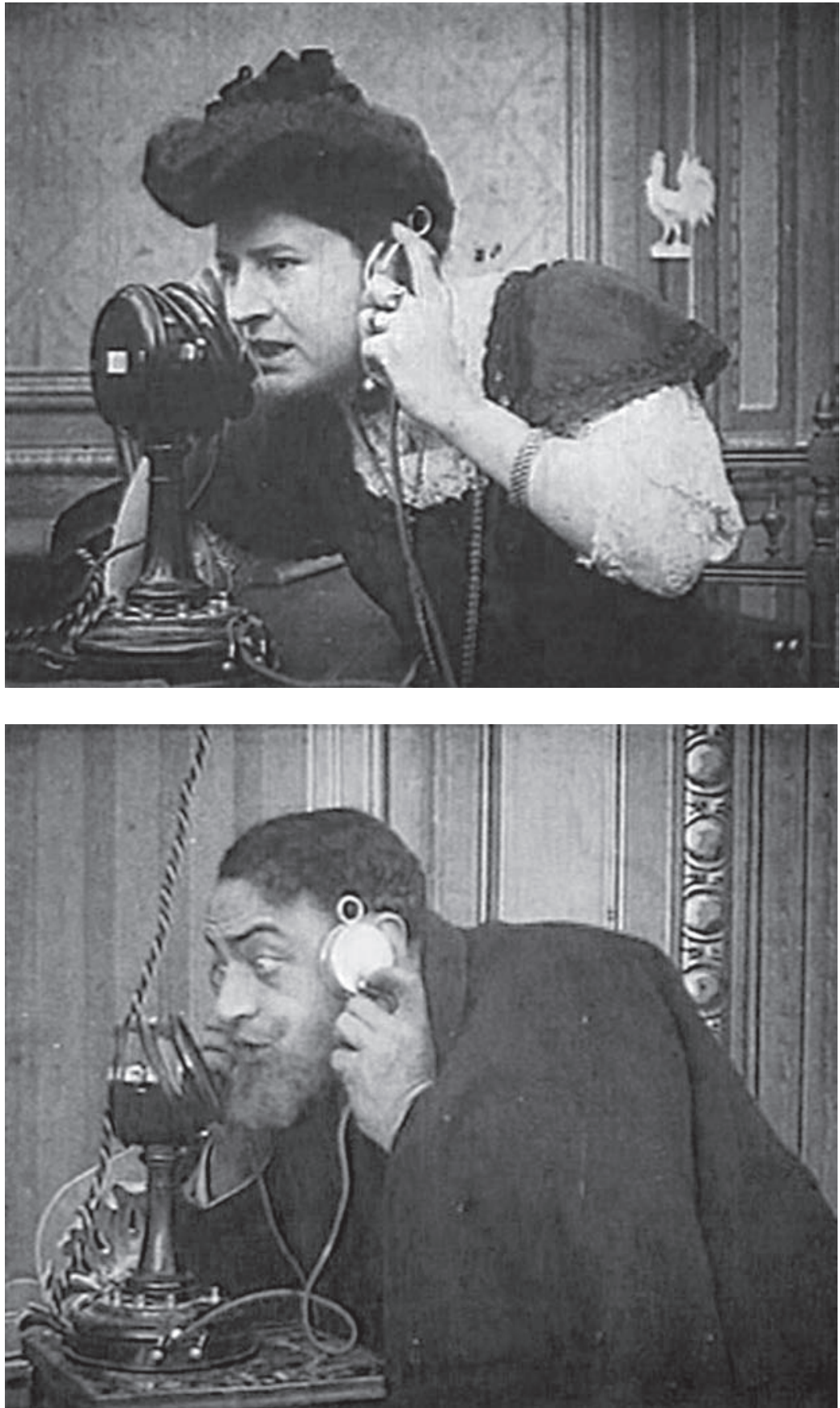

Figs. 4-5. Le médecin du château, Pathé, 1908. 
the complexities of the facial close-up in early film. In the first, Le médecin du château (Pathé, 1908), a bourgeois family is threatened by intruders: the father, a doctor, is drawn away by a false telegram sent by the criminals to tend to another family while the wife is left at home with their child. Menaced, the wife calls her husband on the telephone, and the two are shown in medium close-up: each speaks urgently into the mouthpiece, their quick facial movements vividly communicating their mutual distress. ${ }^{24}$ (Figs. 4-5) The telephone persists as an embedded centerpiece at the end of the film: in the shot of the rescue the action is choreographed around it.

Tom Gunning has discussed André de Lorde’s theatrical melodrama Au téléphone (1901) and two films drawn from it, Le médecin au château and D.W. Griffith's The Lonely Villa (1909), among others. Unlike the filmed rescue melodramas, de Lorde's play ends tragically, with the husband impotently listening to his wife's murder over the phone line, allowing the audience a voyeuristic appreciation of "true" expression as in Proust's fictional painting Devant le téléphone. In De Lorde's play, however, the scene provokes horror, not desire. ${ }^{25}$ Gunning identifies a "return of the repressed" in Griffith's The Lonely Villa: the film includes a long sequence of parallel editing of the couple on the phone that ends with a dramatic interruption of their communication when the intruders cut the line, revealing the threat of "paralysis and impotence" caused by the disruption of modern technology that echoes de Lorde's grisly ending. But he does not recognize the threatening aspects of modern technology in Le médecin du château. ${ }^{26}$

24. On the reconstruction of the film see Barry Salt, "The Physician of the Castle," Sight and Sound, Vol. 54, No. 3, Fall 1985, p. 284-285.

25. Tom Gunning, "Heard over the Phone: The Lonely Villa and the de Lorde Tradition of the Terrors of Technology," Screen, Vol. 32, No. 2, summer 1991, p. 184-196. Gunning explores the "darker aspects of the dream world of instant communication and the annihilation of space and time" in these melodramas of stage and screen. (p. 188) See also Tom Gunning, "The Horror of Opacity: The Melodrama of Sensation in the Plays of André de Lorde," in Jacky Bratton, Jim Cook, and Christine Gledhill (eds.), Melodrama: Stage, Picture, Screen, London, British Film Institute Publishing, 1994, p. 50-61.

26. Tom Gunning, "Heard Over the Phone," p. 192-194. Richard Abel has discussed the struggle between criminals and bourgeois for control of the home and family and of modern technologies in Le médecin du château. Abel, however, understands the alternation of shots of the husband and wife on the telephone as advancing "an unusually sustained structure of suspense" and "eras[ing] the distance between them." (Richard Abel, The Ciné Goes to Town: French Cinema 1896-1914, Berkeley, University of California Press, 1994, p. 193-195) Rescue melodramas like Le médecin du château or The Lonely Villa often place the menaced mother and child in a suburban home or vacation villa, setting up a contrast between isolated and vulnerable locations and the speed and "jostling crowdedness" of urban modernity. 
In Le médecin du château, the telephone brings two people and two spaces together and enables the resolution of the crisis brought about by the couple's separation and the burglars' intrusion into their home. It also registers, however, as an instrument of distancing, lack of reciprocity, and estrangement. In the close-ups of the husband and wife on the telephone, each is shown facing to the left, oriented to the instrument of their communication and the space beyond the frame, in matching profile rather than turning toward one another across the gap that separates them. The rapid facial movements that accompany their speech-semaphores of efficient communication in a crisis-are in tune with the quick gestures and movements of the burglars, husband, patients, and policemen in the medium and long shots in the rest of the film, and retain an element of the "grimaces of curiosity" Gunning discusses. ${ }^{27}$ But here the faces are part of a dramatic sequence and participate in the rhythm of the film's structure of suspense rather than fully breaking the continuity. Hooked up to the telephone, the faces of the wife and husband move quickly, almost mechanically, while their intensive expressions convey the pressure of their drive to communicate their anxiety and fear. Their faces are instrumentalized by the film's mechanization and commodification of time and space: the insistent, restless tempo of the suspense structure; the cutting-up of space; and the pervasive speeding up effected by the various technologies deployed in the narrative (telephone and automobile).

In Le médecin du château, the telephone-face draws us into the narrative, but it also subjects us to estrangement and objectification through the conjoining of face and machine and the fragmentation, mechanization, and recombination of bodies, spaces, and times effected by the film. Wife and husband direct their faces to the mouthpiece and the indeterminate and unknown space off-screen, duplicating and paralleling each other's position and action and propelling their intensified affect over the telephone lines and across the frames of the film. Their faces do not face, and the close view the film offers suggests both the drive to reunite the couple and the contrary forces - not just criminal-that work to separate them. The new technologies of telephone and film produce both connection and separation, proximity and distance, "true" affect and its evacuation through mechanization and repetition. The moral injunctions the film espouses-protect the innocent, fight evil, preserve the (patriarchal) family-are compromised by the visceral thrills the suspense generates. ${ }^{28}$

A somewhat different filmic use of the telephone and the close-up, also involving a married couple, would be realized on the screen in Cecil B. DeMille's

27. Tom Gunning, "In Your Face," p. 21-25.

28. For a classic discussion of the contradictory effects of new technologies see Wolfgang Schivelbusch, The Railway Journey: The Industrialization of Time and Space in the 19th Century, Berkeley, University of California Press, 1977. 

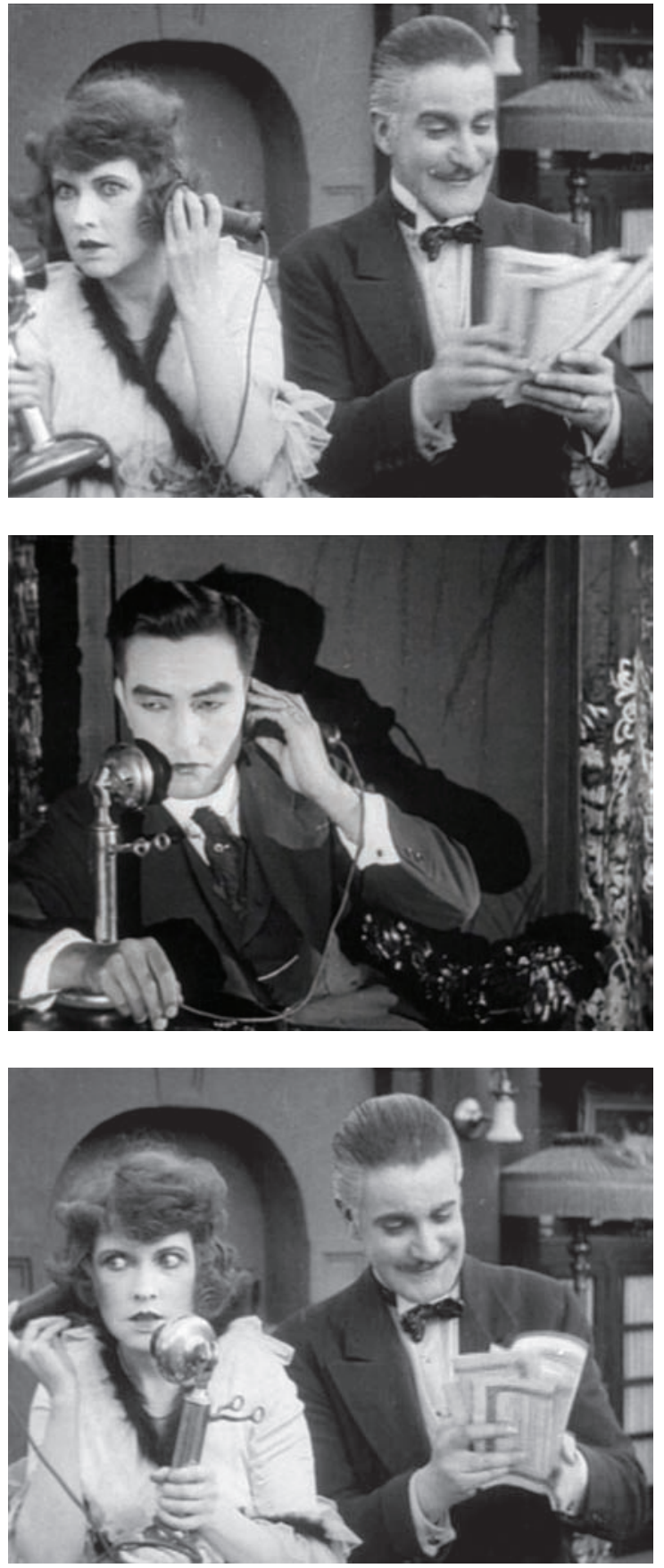

Figs. 6-8. Cecil B. DeMille, The Cheat, 1915. 
The Cheat (1915), a film famous, among other things, for the restrained performance of the Japanese actor Sessue Hayakawa and for faces made expressive by dramatic lighting rather than exaggerated expression. In this film, the telephone is an important link between the protagonists-the socialite Edith Hardy ("The Butterfly"), her stockbroker husband Richard, and her Japanese/Burmese suitor and blackmailer, the "ivory king" Tori/Arakau-and motivates a series of shots "at the telephone" with distinct facial movements and expressions. ${ }^{29} \mathrm{~A}$ crucial scene in which the final assignation between Edith and Tori is arranged by telephone-she owes him sexual favors in repayment of a loan-is shown in a succession of medium close-ups. Preceding the call, Edith and Richard celebrate their financial success-ironically the Hardy's money troubles have just been solved-but their celebration is contaminated by Edith's memory of her bargain with Tori: in the midst of her giddy excitement she suddenly slumps and stares out of the frame. Seated at his desk at home, Tori sighs, checks his pocket watch, looks at the telephone, and makes his call. Edith flashes a nervous false smile when she realizes who is on the line and switches the earpiece to the opposite side, away from her husband, who remains busy with his stock certificates on the right of the frame, gazing at them greedily and shuffling them obsessively. We see Edith's expression of fear and foreboding in reaction to Tori's command "Come tonight" (spelled out by his subtle facial expression and the intertitle), but her reaction goes unnoticed by her husband. As Edith's fear mounts her face becomes fixed, and again she stares off-frame to the left. (Figs. 6-8)

As in Le médecin du château, off-screen space plays an important role in a close-up of a face expressing fear and dread. Edith switches the phone from one side to the other as she tries to keep Arakau's voice and her reaction to it from her husband; she leans further and further to the left, splitting the frame and polarizing the couple more and more, often fixing her gaze-wide-eyed, the whites ablaze, the pupils rolled all the way to the left-on the space beyond the frame or at an oblique angle that suggests absorption and vulnerability. The alternation between sidelong gaze and unfocused stare produces an oscillation between intensive and reflective/reflexive faces: the first breaks up the face's

29. On The Cheat, see Sumiko Higashi, Cecil B. DeMille and American Culture: The Silent Era, Berkeley, University of California Press, 1994, p. 100-112. Due to shifting U.S.-Japan relations in the period of World War I, in 1918 the exotic Japanese "Tori" played by Hayakawa was converted into an exotic Burmese named "Arakau." The Cheat begins with a telephone call, as the hard-working, stressed-out Richard calls his wife at home to tell her to "economize" until his investments pay off. Edith refuses and when Tori walks in she claims that her husband is complaining about her "extravagances-and you." Tori reacts angrily and lunges for the phone, but Edith stops him from making the call. 
unity and points to off-screen space (and thus to Tori, the imminent meeting, the unknown), while the second signals absorption in fearful thoughts. After hanging up, Edith slumps and leans even further into the left corner of the frame. The contrast of faces in this sequence-between Tori's contained concentration and the Hardys' disconnection, distraction and quick shifts and reversals of expression-is striking. With its subdued expressiveness and micromovements, Tori's face gathers its energies and spends them thriftily. Edith alternates between rapid nervous expressions and fixated ones with gaping eyes. Richard's face is exuberantly, greedily gleeful, testifying to the face-shaping powers of capital-it is only before the call that what passes for happiness is interrupted briefly by his recognition that all is not well with his wife.

This sequence from The Cheat suggests the complex interplay of proximity and distance, intimacy and alienation effected by the facial close-up in early film. With one arm on the telephone while the other casts a menacing shadow on the wall behind him, Tori/Hayakawa hooks up to the network of faces and restrains his own, the self-possessed master of the new technologies of face, phone, and film (fig. 7); meanwhile Edith and Richard's polarization of affect and divided attention suggest the contradictions, instabilities, and shocks to which subjectivity, individuality, and intimacy are increasingly subjected in Western modernity. $3^{\circ}$ (Figs. 6 and 8)

\section{INTER-FACES}

For Simmel, the face has a privileged status within modernity: as a visual focus for reciprocity and inter-individual seeing; as a model of the unity in variety of society; in its special relation to interiority and appearance; and in its complex aesthetic significance. His critical concepts of the mutual dependency of internal and external life and of proximity and distance within modernity suggest the importance of spacing for the face. Proust writes of the monstrous kiss, the faces of paroxysm and doubling, and the telephone-face equivalent of the alloy of intimacy and voyeurism in genre painting. Redon produces hybrid and serial faces with composite and centrifugal structures, uncanny and desubjectifying effects, and ambiguous affects. Cinematic close-ups of expressive faces are situ-

30. Tori's dominant individualism, self-control, and sadistic power will be punished in the final courtroom scene, where the white, bourgeois, Western couple will triumph through self-sacrifice and the assertion of "natural" superiority: Richard protects his wife by assuming guilt for shooting Tori; to save her husband Edith displays the branding of her body by the perverse, evil Tori, and the righteous vengeance of the courtroom mob is barely held in check by the Law. 
ated within suspenseful filmic compositions of space and time, articulating a complex dialogue of communication and separation. Proust's novel invokes painting and photography and contrasts reading and seeing; Redon produces faces in the interplay of image and text; the films' marriage of suspense and technology is shaped by theatrical and literary precursors. From fictive genre painting to dream to melodrama, from monstrous kiss to monstrous hybrid to monstrous mechanized spouse, these works mobilize complex spacings and aestheticizations of the face, conjoining the too close and the too far, reconceiving interiority and exteriority, replaying modernity's losses and thrills and reorganizing its forms. So close yet so far away: such faces are suspended in a matrix of changing media and the spatiotemporal dislocations of modernity. 